\title{
The ACRL Standards for Faculty Status: Panacea or Placebo
}

\author{
John N. DePew
}

The ACRL Standards for Faculty Status were designed to help forward the role of academic librarians as information facilitators. While gains have been made in the years since their adoption, the standards requiring tenure and faculty rank are unrealistic and counterproductive to the growth of librarianship as a profession. Standards 5 and 6 should be modified to remove artificial requirements and misleading labels that inhibit the profession from developing on its own merits. Suggestions for revision are included in this paper.

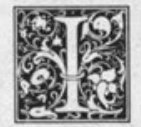

$t$ has been thirteen years since Arthur M. McAnally wrote his lucid defense of faculty status for academic librarians, years in which the profession has seen the creation of a set of standards for faculty status, guidelines for their implementation and their wide-spread acceptance by college and university administrators. ${ }^{1}$ Almost 79 percent of academic libraries now have some sort of faculty status. * This is a major triumph for the profession and an indication that we have made great progress toward being accepted as colleagues and equals by teaching faculty-or is it?

The search for faculty status commenced many years ago when it was felt that the only way librarians could gain respect and legitimacy for their profession was to be judged and accepted by the same standards as teaching faculty. ${ }^{2}$ There were ample reasons for believing this in the late nineteenth and early twentieth centuries, when the clerical, housekeeping, and intellectual tasks of librarianship were commingled and difficult to separate. The inferior status of librarians was exacerbated by the small size of library staffs, forcing them to perform all types of library activities (professional or otherwise) in order to maintain service and by the poor education, by faculty standards, of most librarians. Early leaders believed faculty status would encourage highquality persons to enter the profession, improve service, and change faculty perceptions of librarianship.

This long-sought goal was difficult to reach until after World War II, when the rapid growth of academic institutions forced libraries to expand and staffs to increase. Growth in collections brought the need for specialization and expanded instruction in the use of materials. Faculty and students required expert assistance both in locating information and in the use of a bewildering variety of bibliographic tools, reference sources, and research materials. Library schools established graduate programs and librarians became better

*A survey of 836 academic libraries in the spring of 1981 by the author and Anne Marie Allison revealed that 78.8 percent had some degree of faculty status. A report of the survey will be published in the near future.

John N. DePew is associate professor, School of Library and Information Studies, Florida State University, Tallahassee. 
educated and more sophisticated in their role as information facilitators, giving less attention to their earlier and often primary concern as custodians of recorded knowledge. Later, with the availability of shared cataloging, the application of scientific management techniques to library operations, the continuing education of staff, automation, and increased standardization, many housekeeping functions no longer absorbed the time of professional staff. In the late seventies and early eighties, clear distinctions were being made between the duties of professional librarians and support staff. The former were able to spend more time fulfilling the information needs of students and faculty, leaving routine operations in many departments to technical assistants and clerks. This situation was, of course, tempered by the size of a library, but, with the availability of bibliographic and other information through memberships in networks and consortia, even the smaller institutions were able to give more attention to improving services and developing new approaches to building collections.

For the first time in our developing profession, the stage has been set for librarians to move to a higher level in creating new and imaginative programs, working closely with faculty in meeting the information needs of the future. Librarians are becoming accepted and respected as professionals on their own merits. The ACRL standards encouraged professional autonomy and experimentation, collegial governance, association with teaching faculty, continuing education and staff development, research, and publication. ${ }^{3}$ Most libraries now have some form of participatory management that enables the staff to have a significant effect on library policies. Many library directors have given their professional staffs the freedom to work independently, without being rigidly tied to desks or time clocks. In a few cases, librarians have implemented an academic form of governance (encouraging participation and reducing the inhibiting qualities of hierarchical structures). Positions are being filled with persons who have advanced degrees in many different subject areas; incumbents are often work- ing on advanced degrees or gaining skills through workshops, conferences, or other educational programs. Professional journals frequently publish articles reporting the results of very respectable research and innovative programs.

Hopefully these are indications that the profession is developing momentum toward the establishment of the long-sought but elusive philosophical base that will provide a foundation for building credibility, respect, and understanding for librarianship as a profession.

Yet, all is not well with the implementation of faculty status in academic librarianship. Since 1971, many articles, essays, and studies that discuss faculty status in a positive light have been published. Recently, however, the tenor of these articles has become negative as librarians try to cope with the difficulties of wearing the hats of two professions. The strains of bearing the joint responsibilities of a teaching faculty member and a professional librarian are beginning to leave their marks. Stella Bentley's study on collective bargaining and faculty status revealed the feelings of some librarians about this dilemma. When asked what they thought should be done to improve their status on campus, several librarians responded:

The status of librarians on this campus might improve as the quality of librarianship improves in each librarian.

Faculty status is the wrong model for librarians. More attention to librarianship and less concern with faculty status. I would prefer to see librarian status.

The largest number of comments fell into the category of "better service from librarians and less concern about achieving faculty status." ${ }^{\prime 5}$

Since most librarians still come into entry-level positions with only a master of library science degree, those who are hired by institutions that evaluate them by teaching-faculty standards are often placed in an extremely difficult situation. Many schools now require that faculty librarians have a second degree, in addition to research, publishing, and service, in order to qualify for tenure. As Davey and Andrews noted in their article on the "Im- 
plications of Faculty Status for University Librarians," faculty usually must qualify for tenure within seven years. ${ }^{6}$ However, most schools inform unsuccessful tenure candidates in the sixth year, with the evaluation procedure taking place about fiveand-one-half years after initial employment. Therefore, to meet the normal requirements in many institutions:

It would be virtually impossible for a librarian coming directly from library school to a university where librarians have faculty status to pursue an additional degree and meet the standards for tenure in five and one-half years. ${ }^{7}$

Some libraries that did make a serious effort to implement full faculty status in accordance with the ACRL standards have begun to have second thoughts:

The dark cloud that appeared on our horizon is the one which hangs over many college campuses. The predicted decrease in the size of the student applicant pool and the uncertainty of the times led the Board of Trustees to seek a greater measure of flexibility in the management of the institution. It became increasingly difficult for a faculty member to gain tenure, and every tenurable position gained a new importance. To help make decisions fairly, the Faculty Personnel Committee raised its standards. Among the prerequisites for gaining tenure is engagement on the doctoral level in specialized scholarly research which is recognized as significant by one's peers, as well as favorable reports ... from ... students ... concerning one's effectiveness as a teacher. It was obvious that a librarian, usually not comparably educated and seldom in the classroom, was at a serious disadvantage. ${ }^{8}$

Cieslicki, describing the situation at Dickinson College in Carlisle, Pennsylvania, stated that the majority of librarians who reached tenure review during the two years after the implementation of full faculty status were denied tenure, creating shock and bitterness among the library faculty.

Not only has it been difficult for dedicated and competent librarians to achieve tenure, there is a question as to what it and full faculty status really mean. At Southern Illinois University, Carbondale, a survey was conducted to determine the teaching faculty's perceptions of the academic librarians at the university. Al- though 57 percent of the respondents were in favor of academic librarians having faculty rank and status, many felt they should conduct research. On the other hand, of the three responsibilities of a faculty member, that is, teaching, research, and service, an overwhelming majority thought service was the most important responsibility of a librarian. Several of the "teaching faculty felt that the librarians' role was coequal but different: 'Because the library is not a degree granting department, faculty rank and status should not be awarded.' ",9 Another faculty member said, "The only legitimate faculty rank for librarians would be [for] those with crossappointment in an academic department."

Hardly an issue of the Journal of Academic Librarianship or College \& Research Libraries is published that does not have some article or comment about faculty status. Additional arguments for the benefits of such status and how it may improve library service can be persuasive:

Academic librarians have turned to the faculty model for two reasons: (1) because it can approximate more closely the norms for independent judgement needed to carry out our professional responsibilities in an optimum manner, and (2) because the "big man" system of governance has some very serious defects. ${ }^{11}$

The reasons for elevating the general status of librarians are valid today, but not those for attaining faculty status. Faculty status is inappropriate for librarians because it creates tensions that obscure the proper role of the librarian, and it interferes with the effective delivery of library services by diverting librarians' energies and attentions from those services. It causes confusion in the minds of colleagues and patrons. Pauline Wilson did an excellent job of describing the problem in her article, "Librarians as Teachers: the Study of an Organization Fiction." ${ }^{\prime 12}$ Proponents of faculty status should carefully read her arguments against labeling librarians as faculty. The case she makes against librarians as teachers is solid and convincing. She quotes the sociologist Amitai Etzioni:

The costs [of claiming to be faculty] are those 
typically associated with persons seeking to pass for what they are not: a guilty feeling for floating a status claim without sufficient base and a rejection by those who hold the status legitimately. $^{13}$

Although there are no studies to substantiate these feelings, many would agree that the majority of librarians who claim faculty status do so with less than full confidence that they fit the criteria established by the teaching faculty itself. Those who are totally comfortable in that role, fitting all the criteria, probably teach more than half-time anyway; in which case, are they librarians?

Faculty status has sometimes been confused with academic status. McAnally explains the difference:

Faculty status for librarians is defined as the possession of all or most of the privileges of the classroom teaching faculty, including faculty rank. Academic status is held to be the possession of some but not all usual faculty privileges, with definite classification as academic but always without faculty rank. ${ }^{14}$

There is no denying that librarians need access to faculty meetings and committees, and they must have the freedom to perform their duties in a responsible, productive, and creative way. Unfortunately, the search for faculty status will continue to divert librarians from these goals, confuse those they serve and work with, and demean librarians as professionals in their own right, grasping for something they are not.

Is there an alternative? Few have written in support of civil service or professional status. However, the latter is attractive because it allows librarians to build the types of programs and collections our institutions need, in a cooperative atmosphere, without the vocational label that civil service job titles often connote, and without the unnecessary burden of emulating the teaching faculty. Librarians would have the opportunity to demonstrate their professional skills and participate in scholarly activities, without being accused of "riding the coattails of another profession, " in the words of the late William Axford. ${ }^{15}$

In order to do this, however, the ACRL standards should be modified. Specifi- cally, those standards dealing with tenure and promotion-standards 5 and 6-need to be changed. Standard 5 addresses tenure, a requirement that, as already noted, is proving to be of great distress to those librarians who do not presently have it. The standard presently reads:

5. Tenure. Librarians should be covered by tenure provisions the same as those of other faculty. In the pretenure period, librarians should be covered by written contracts or agreements the same as those of the faculty. ${ }^{16}$

The tenure stream is not appropriate for librarians because they do not do the same things faculty members do, and therefore should not be unjustly penalized by an unsuitable set of criteria. Tenure was the nemesis of the otherwise successful application of the ACRL standards at Dickinson College. In fact, the Dickinson librarians found it so unworkable they wrote it out of their requirements and created a new status of "tenured librarians." The implication being that librarians would be evaluated as librarians and granted tenure based on what librarians should do, and not on the same basis as teaching faculty. This seems to be an eminently reasonable proposal. It was accepted by both the Dickinson administration and faculty. We see more and more librarians choosing this approach or selecting contracts of continuing employment or indefinite contracts when they have the choice. I suggest that the Committee on Academic Status of ACRL reexamine Standard 5 and change it to read something like this:

5. Contracts. Librarians should be covered by written contracts or agreements similar to those of the faculty. After a suitable probationary period and peer review, librarians should be given a contract of continuing employment, subject to peer review every five years (or some other appropriate time period).

Modifying Standard 5 in this way would eliminate the inappropriate and demoralizing demands of the tenure process and continue to give at least as much protection as tenure, especially in these times of economic stress. In addition, it would help ensure quality performance and encourage research and publication.

Standard 6 deals with promotion and 
faculty rank and also needs modification:

6. Promotion. Librarians should be promoted through ranks and steps on the basis of their academic proficiency and effectiveness. A peer review system similar to that used by other faculty is the primary basis of judgement in the promotion process for academic librarians. The librarians' promotion ladder should have the same titles, ranks, and steps as that of other faculty. ${ }^{17}$

The arguments are many and long as to why faculty titles should be used, for example, to ease admission to faculty councils, to condition others to realize that librarians are as important to higher education as the teaching faculty, to gain a place in collective bargaining agreements, and so on. John H. Moriarty brought the advantages of faculty titles to the attention of the profession when he wrote in 1970:

. . . a librarian rated as Librarian III does not get a travel grant reserved for professors. Or a new president comes to office and appoints a campus-wide committee for some key purpose and forgets to name any librarian member. The oversights, the "pin-pricks" brought on by any quasi-status are pointlessly but cruelly demeaning; they sour able people, they make present librarians only halfhearted recruiters of new professionals; or, as in the past, they drive able librarians out of the profession. ${ }^{18}$

These reasons are also persuasive, but librarians currently participate in curriculum and program decisions, and will continue to do so. They are acknowledged to be as important as the teaching faculty in many institutions (where this is not thought so, faculty rank is certainly not going to make any difference). And, librarians will continue to be successful in participating in collective bargaining units. It is a "fiction," as Wilson put it, to believe that the rank of Professor or Instructor will make any difference to any group other than librarians.

The ranks and titles of the teaching faculty should not be used because they are the labels of another profession; understood not only by the members of that profession as to what they denote, or stand for, but also by the lay public. When librarians use them for their own, they undermine the integrity of their own profession, and in a real sense deny it, by trying to use what Robert Pierson calls the "protective coloration" of another profession to label it what it isn't. ${ }^{19}$ Librarians are not employed as teachers but as librarians, and thus should be proud to admit to what they are. Whether Associate Librarian, Librarian IV, or University Librarian, ranks and titles should reflect what the person does and is, and not be an attempt to wrap a cloak of another profession about one's shoulders. Therefore, the Committee on Academic Status should also consider modifying Standard 6, changing it to read:

6. Promotion. Librarians should be promoted through ranks and steps on the basis of their professional proficiency and effectiveness. A peer review system similar to that used by faculty is the primary basis of judgement in the promotion process for academic librarians. The librarians' promotion ladder should have the titles, ranks, and steps of Assistant Librarian, Associate Librarian, Librarian; or Librarian I, II, III, IV, V (or the equivalent).

Studies examining faculty status over the last decade report that librarians have made great progress in achieving many of the standards, but with significant exceptions in the area of tenure, length of appointment, rank, and leaves. ${ }^{20}$ Thus, even after more than a decade of "implementation," it appears that full faculty status is almost impossible to achieve. Breakdowns most often occur in the areas of tenure, rank, leaves, and length of appointment, creating a sort of quasi-status. Moreover, a recent study by Thomas English reveals that the trend toward faculty status has stopped and may have even reversed. ${ }^{21}$ If this is so, the profession may already have reached the high-water mark in its search.

ACRL should revise the standards in order to make them attainable and enable librarianship to grow as a profession on its own merits. For those who feel the present standards are realistic and taken seriously by both the profession and academe, a simple test could be administered to gauge the effectiveness of their enforcement. The following is from the implementation and enforcement section of the standards:

3. Investigate all violations of these standards. 
4. Invoke the following sanctions against institutions . . . found . . . to be in violation of any [italics mine] or all of these standards:

a. Publicize the violation and the institution concerned in College \& Research Libraries News and other appropriate publications.

b. Refuse to accept advertisements in any ALA publication for positions at that institution.

c. Discourage its members from accepting employment at that institution, through notices in its publications and other means. ${ }^{22}$

One does not have to search College $\&$ Research Libraries News to determine if these sanctions were or are being carried out. As noted earlier, 79 percent of the academic libraries in the United States have some sort of faculty status, but how many have full faculty status? If the ACRL were to implement the sanctions, there would be virtually no advertisements for job openings in the News and most of its pages would be filled with notices to members to avoid applying to the hundreds of libraries that are not in full compliance. The standards and the enforcement mechanisms are unrealistic, ineffective, and demoralizing.

ACRL should reexamine the standards in light of the experience of the past decade and revise standards 5 and 6 , removing the tenure and faculty rank requirements. The remaining standards should be left as they are, except to make them consistent with "librarian" versus "faculty" status and to change the sexist language. With the modifications suggested in this paper, the standards can become attainable and meaningful, both to the profession and to its clients. By divesting themselves of the albatross of faculty status, academic librarians can steer a steady new course toward librarian status, and will have a much better chance of achieving their true goal: the provision of useful information on a timely basis to meet the needs of users of academic libraries. To paraphrase Louise Sherby:

If academic librarians would recognize their role as one of real worth, then perhaps a true professional attitude toward the field of librarianship could develop naturally. There would no longer be a question of "librarians or faculty members"; rather they would be recognized as valued and valuable... colleagues who happen to be librarians. ${ }^{23}$

\section{REFERENCES}

1. Arthur M. McAnally, "Status of the University Librarian in the Academic Community," in Jerrold Orne, ed., Research Librarianship: Essays in Honor of Robert B. Downes (New York: Bowker, 1971), p. 19-50.

2. McAnally, p. 19.

3. "Standards for Faculty Status for College and University Librarians," College \& Research Libraries News 35(A): 112-113 (May 1974).

4. Stella Bentley, "Collective Bargaining and Faculty Status," Journal of Academic Librarianship 4:80 (May 1978).

5. Ibid.

6. Nancy Davey and Theodora Andrews, "Implications of Faculty Status for University Librarians, with Special Attention to Tenure," Journal of Academic Librarianship 4:73 (May 1978).

7. Ibid., p. 73.

8. Dorothy H. Cieslicki, "A New Status Model for Academic Librarians," Journal of Academic Librarianship 8:79 (May 1982).

9. M. Kathy Cook, "Rank, Status and Contribution of Academic Librarians as Perceived by the Teaching Faculty at Southern Illinois University, Carbondale," College \& Research Libraries 42:221 (May 1981).

10. Ibid.

11. Emily Alward, "Must it be Autocracy or Chaos? . . . Some Thoughts on the Academic Status Dilemma," Journal of Academic Librarianship 8:30 (Mar. 1982).

12. Pauline Wilson, "Librarians as Teachers: the Study of an Organization Fiction," Library Quarterly 49:146-62 (Apr. 1979).

13. Ibid., p. 158. As quoted from Amitai Etzioni, ed., The Semi-Professions and Their Organizations (New York: Free Press, 1969), p. vi-vii. 
14. Davey and Andrews, p. 72.

15. H. William Axford, "The Three Faces of Eve: Or the Identity of Academic Librarianship; A Symposium," Journal of Academic Librarianship 2:277 (Jan. 1977). Although Axford was in favor of faculty status. See R.M.D., "H. William Axford (1925 to 1980)," Journal of Academic Librarianship 6:329 (Jan. 1981).

16. "Standards for Faculty Status," p. 112.

17. "Standards for Faculty Status," p. 112-113.

18. John H. Moriarty, "Academic in Deed," College \& Research Libraries 31:17 (Jan. 1970).

19. Robert M. Pierson, "Roles, Symbols, Rewards," Journal of Academic Librarianship 2:285 (Jan. 1977).

20. There are many studies on this subject. For example, see Association of Research Libraries, Office of Management Studies, Systems and Procedures Exchange Center, The Status of Librarians: An Overview. Kit 61 (Washington, D.C.: Association of Research Libraries, 1980); Greg Byerly, "The Faculty Status of Academic Librarians in Ohio," College \& Research Libraries 41:422-29 (Sept. 1980); Ross Davidson, Connie Capers Thorson, and Margo C. Trumpeter, "Faculty Status for Librarians in the Rocky Mountain Region: A Review and Analysis," College \& Research Libraries 42:203-13 (May 1981); John N. DePew, "Faculty Status in Florida," Florida Libraries 28, no. 1: 4-5 (Jan.-Feb. 1978); Alice Manchikes and George Crabb, "A Survey of Faculty Status Policies for Librarians in Kentucky and Surrounding States," The Southeastern Librarian 26:219-25 (Winter 1976); and Prabha Sharma, "A Survey of Academic Librarians and Their Opinions Related to Nine-Month Contracts and Academic Status Configurations in Alabama, Georgia, and Mississippi," College $\mathcal{E}$ Research Libraries 42:561-70 (Nov. 1981).

21. Thomas G. English, "Librarian Status in the Eighty-Nine U.S. Academic Institutions of the Association of Research Libraries: 1982," College \& Research Libraries 44:205 (May 1983).

22. "Standards for Faculty Status," p. 113.

23. Louise S. Sherby, "Academic Librarian: Librarian or Faculty Member?" in Norman D. Stevens, ed., Essays from the New England Academic Librarians' Writing Seminar (Metuchen, N.J.: Scarecrow, 1980), p. 54. 